\title{
Analysis on the Path of Classroom Teaching of Ideological and Political Theory Courses in College
}

\author{
Mengyang Han
}

\author{
China Jiliang University, Hangzhou, 310018, China
}

*Corresponding author. Email:598046643@qq.com

\begin{abstract}
The teaching of ideological and political theory courses in colleges plays an important role in helping college students lift their power, earnestly implementing the fundamental task of strengthening morality education, and deeply studying ideological theory to arm the mind. At present, ideological and political class teaching in colleges is facing some adversities: the teaching environment is not complete; educators' classroom control ability is not strong; The educational object's classroom involvement state is not good. Therefore, colleges should create a good classroom teaching environment, teachers should improve capability of independent innovation, and students should integrate themselves into the class. Through the coordination and cooperation among universities, teachers and students, the ideological and political course in colleges will be built into a course that will benefit college students for life, thereby pushing the classroom teaching of ideological and political course to a new height, and effectively enhancing the affinity and effectiveness of classroom teaching of ideological and political course. With the convening of the National Conference on Ideological and Political Work in Colleges and Universities, the Party and the state pay more and more attention to the classroom teaching construction of ideological and political theory courses in colleges, and constantly improve and perfect the discipline and order of classroom teaching. The paper analyzes the current situation of classroom teaching of ideological and political theory courses in colleges, uncovering the difficulties that the course is facing, discussing the adversities and the root of the problems, and finally figuring out some ideas to implement classroom teaching reasonably.
\end{abstract}

Keywords: Ideological and political theory courses in colleges, Classroom teaching, Path.

\section{THE IMPORTANCE OF CLASSROOM TEACHING OF IDEOLOGICAL AND POLITICAL COURSES IN COLLEGES}

The classroom teaching of ideological and political course in colleges is an educational activity in which specialized teachers are arranged in accordance with national training requirements and curriculum standards, and students are guided to learn and master Marxist theoretical knowledge and practical skills in a purposeful, planned and organized manner. Therefore, from the micro level, the quality of classroom teaching is directly related to whether college students can improve dialectical thinking and solve practical problems; From the middle level, the implementation of classroom teaching is related to whether colleges and universities can effectively implement the basic educational task of cultivating people through virtue; From a macro perspective, the effectiveness of classroom teaching is related to whether we can deeply study the latest theoretical results to equip people's minds.

\subsection{To Help Students Improve Their Ability to Combine Theory with practice}

Ideological and political class teaching is an effective way for colleges to guide students to work hard in theoretical study and improve practical skills. From the theory of teaching level, the classroom teaching of ideological and political courses has the functions of cultural infiltration and cultural dissemination. On the one hand, through classroom teaching, teachers choose to impart knowledge consistent with the purpose of education to students, and guide students to explore dialectical thinking in courses such as "Ma Yuan", "Si Xiu", "Xing Ce" and "Gang Yao". On the other hand, teachers absorb and reform theoretical knowledge, teach students to look at problems with correct viewpoints, positions and 
methods, carry forward healthy and progressive socialist ideas, solve problems existing in students' ideological concepts, and help students improve their dialectical thinking ability; From the practical teaching point of view, the classroom teaching can standardize students' behavior and stimulate their practical ability. Teachers transform external social norms into students' inner consciousness in classroom teaching, and externalize students' consciousness into actions through practical activities. In addition, teacher should also guide the student to launch a wide range of social investigation, cultivate the student's consciousness of the problem, teach the student to analyze the reasons for the existence of the problem, grasp the essence through the phenomenon, focus on solving the actual problem.

\subsection{To Effectively Protect Colleges to Carry out the Fundamental Task of Strengthen Morality Education}

"Moral cultivation is the foundation of colleges and the fundamental task of ideological and political work" [1], therefore, classroom teaching is the crucial link to implement the task of "strengthen morality education". First of all, the classroom teaching of ideological and political courses answers the question of "who to train" in colleges. Colleges promote students' integrated development through classroom teaching of ideological and political courses, and educate students to care about the international development situation, recognize China's actual conditions, correctly understand the mission of the age with a broad world vision, motivate students devoted to the construction of the Chinese dream and take on the responsibility of national rejuvenation. Secondly, the classroom teaching answers the question of "how to train people" in colleges. The classroom teaching actively organizes practical activities through innovative teaching method and the power of new media technology, attracting students to integrate into teaching activitie and promoting students' development in practice. Finally, the classroom teaching answers the question of "for whom to train people". From the social goal of ideological and political education, the classroom teaching of ideological and political course serves the great cause of the party and the country, and cultivates new people who love the party, love their country, stand firm, have a solid theory and have the courage to contribute for the construction of socialism with Chinese characteristics.

\subsection{Study Theory in Depth and Arm the Mind with Advanced Ideas}

The classroom teaching of ideological and political courses in colleges always "play to maintain social stability, promoting the development of social and political action"[2]. Through teachers' teaching, students armed themselves with $\mathrm{Xi}$ Jinping Thought on
Socialism with Chinese Characteristics for a New Era, grasp political awareness and standardize political behavior. Fundamentally speaking, proletarian political parties need to adjust the spiritual world of young students through systematic classroom teaching of ideological and political courses, guide students' thoughts and behaviors with positive public opinion, stimulate students' spiritual motivation, strengthen the correct political direction, and realize young students' recognition of political roles. At present, the ideological and political course integrates the latest theoretical achievements into classroom teaching, which not only conforms to the requirements of socialist development, but also meets the needs of young students' integrated development, so that students can reach an agreement in ideological and political affairs, firmly follow the party, and move forward towards the situation of national unity and social stability. However, the special value of classroom teaching of ideological and political course is irreplaceable and incomparable to other courses.

\section{THE ACTUAL ADVERSITY OF CLASSROOM TEACHING OF IDEOLOGICAL AND POLITICAL THEORY COURSES IN COLLEGES}

To improve the present situation of classroom teaching of ideological and political course, we should study all aspects of classroom teaching process, find out the main problems and solve them, so as to promote the steady development of classroom teaching. The teaching environment, the educator and the object of education, as the three essential elements, play an important role in ensuring the steady operation of the classroom teaching. However, there are different problems among teaching environment, educators and educational objects in the course of ideological and political teaching in colleges in China, which makes the teaching effect of ideological and political courses fail to be significantly improved.

\subsection{Classroom Teaching Environment is not Perfect}

With the development of information technology and Internet media, colleges actively explore the function of "network education", and combine the advantages of Web-based instruction and classroom teaching to blazing new trails. Although this "double-line teaching" [3] mode breaks the space-time boundary of the traditional classroom, it also brings severe unprecedented new challenges to the construction of classroom teaching environment. First of all, online ideological and political classroom teaching is vulnerable to the impact of negative information on the Internet, which often confuses students' value judgment and has a negative impact on the effectiveness of classroom teaching. Apart from this, because the boundaries of teaching space are broken, teachers can't accurately confirm students' actual learning progress and 
learning effect, and can't give students timely guidance. Secondly, because the offline classroom teaching adopts the teaching method of large class, students from different classes and majors are concentrated in the same classroom for teaching, and the available teaching methods are limited, which makes it difficult to guide and educate students effectively, and lacks the interactivity and interest of classroom teaching. Finally, offline ideological and political practice courses lack a long-term formal teaching place, and often units and institutions refuse the observation and investigation activities of social practice teaching, and some practice courses have poor teaching environment, which makes it impossible to carry out practical teaching at all. Due to the imperfection of the classroom teaching environment, it is difficult for the Web-based instruction to connect with the classroom teaching content, which deviates from the original intention of "double-line teaching" and makes the teaching results unsatisfactory.

\subsection{Educators' Classroom Control Ability is not Strong}

Ideological and political courses are characterized by wide contents and fast changes, which requires teachers to cover a wide enough range of contents, which increases the difficulty of teachers' teaching virtually. In addition, most ideological and political teachers still use traditional teaching concepts, boring teaching contents and backward teaching methods in actual classroom teaching, which makes classroom teaching fail to achieve ideal results. From the perspective of teaching subject, individual teachers still adopt traditional teaching ideas, instill theoretical knowledge in students with obscure technical terms, ignore the students' main role, and keep zero communication and interaction distance with students all the time, so the classroom atmosphere is boring. From the perspective of teaching content, some teachers rely too much on teaching materials, do not pay attention to students' actual needs, and are out of touch with students' reality. In addition, some teachers don't pay attention to the exploitation and utilization of instructional resource, which opens the distance between theory and reality, and only makes students feel big and empty, unwilling to go deep into theoretical study. From the perspective of teaching methods, teachers adopt a single teaching method in classroom teaching, which neither interacts with students positively nor teaches according to the student's ability, thus reducing students' attention to classroom teaching.

\subsection{The Education Object's Classroom Input State is not Good}

Because ideological and political courses have strong political and theoretical characteristics, it is difficult for students to learn and grasp the relevant theoretical knowledge thoroughly in classroom teaching.
On the one hand, students often play the role of passive learning in classroom teaching, preconceived that the learning content is difficult to understand, and there is almost no communication and interaction between students and teachers. Some students will feel that the teaching content has little to do with their real life, so there is no need to study it in depth; Some students think that the teaching content and their major is not appropriate, learning enthusiasm is not high; Some students think that the ideological and political course is a public course, so they don't need to be as serious as professional courses and have less professional identity. On the other hand, the collective teaching form of class teaching system makes it impossible for teachers to consider the actual needs of every student in all directions, and it is also difficult to know the learning degree of students in due course, and it is impossible to carry out targeted teaching according to the specific situation of students. Combined with boring teaching content and single teaching method, students will unilaterally think that the essence of classroom teaching is simple theoretical preaching, which weakens students' participation in class and makes them unwilling to take the initiative to participate in class.

\section{SOLUTIONS TO CLASSROOM TEACHING OF IDEOLOGICAL AND POLITICAL THEORY COURSES IN COLLEGES}

In the face of the practical adversity of ideological and political classroom teaching, colleges and universities should be the first to create a positive campus environment, optimize the classroom teaching environment and perfect the classroom teaching system; Teachers also need to further improve their professional quality, enrich and develop teaching content, and innovate teaching models; Students need to actively participate in classroom teaching, independently accept rich theoretical knowledge, consciously strengthen behavioral activities, and effectively improve the effectiveness of classroom teaching.

\subsection{Colleges Should Create a Good Teaching Environment}

A good classroom teaching environment can not only improve students' cultural and ideological and moral qualities, stimulate students' learning enthusiasm, but also activate the campus atmosphere. First of all, colleges should "strengthen the construction of campus network environment, make full use of mass media and Internet information technology" [4], advocate the integration of important discussions on $\mathrm{Xi}$ Jinping's ideological and political education into the online battleground, resist the ideological infiltration of negative corruption, and guide the online classroom teaching atmosphere to develop in a healthy and elegant 
direction. Secondly, Colleges should strengthen the construction of humanistic environment on campus, create reading corners in the classroom, create collective learning situations in the classroom, increase the teaching activities of teaching through entertainment, create a teaching atmosphere of strong style of study, so that students can learn knowledge imperceptibly, thus giving full play to the educational function of classroom teaching. Finally, Colleges and universities should strengthen the construction of the natural environment, good education courses practice teaching base construction, perfect the various activities, to harmonize the work of various departments in the school, improve the practice teaching risk prevention mechanism, safely lead the students to visit, investigate, visit, social services, and other practical teaching activities, the growth of the students' knowledge, help the students comprehend the truth in practice.

\subsection{Teachers Should Enhance Their Own Comprehensive Quality}

"The key to running ideological and political courses well lies in teachers, and the key lies in exerting teachers' enthusiasm, initiative and creativity" [5]. Only when teachers update their teaching ideas in time, consciously study theories, enhance the reserve of professional knowledge, and actively innovate and develop teaching methods, can they effectively educate students. First of all, Teachers timely update the teaching philosophy, abandon the outdated teaching philosophy, "student-oriented", respect students' independent personality and subjective status, have a deep understanding of students' development. The teaching activities should be designed according to the students' thoughts, and the students should be guided to think independently step by step so that they can feel the satisfaction of learning. Secondly, teachers should read more Marxist original works, constantly improve their ideological and theoretical level, explain the theoretical knowledge thoroughly, combine the actual cases in social life, interpret the important and difficult contents of teaching completely and accurately, and attract students with the theoretical foundation behind them. Finally, teachers should actively explore teaching methods. For example, before classroom teaching, accumulate rich teaching cases and design classroom teaching activities; In classroom teaching, multimedia equipment is used to enliven the classroom atmosphere, explain theories in a language close to students' life, set up questions and exchange links, strengthen interaction with students, and arouse students' learning enthusiasm.

\subsection{Students Should Actively Integrate in the Classroom}

Classroom teaching is a two-way activity in which teachers teach students knowledge and students start learning consciously and purposefully. Students need to constantly improve their subjective initiative, play the main role, master new theories and new viewpoints, and apply them to practice. First of all, students should actively interact with teachers on an equal footing. Both students and teachers have independent and equal personalities, and there is no relationship between coercion and repression. Students should actively communicate with teachers in classroom teaching to express their views and opinions, which will influence teachers' thoughts in the interaction and promote both teaching and learning. Secondly, students should fully recognize the value of the teaching purpose and the teaching content. From the short-term goal, ideological and political teaching needs to meet the requirements of society and individual development needs; From the long-term goal, ideological and political teaching should safeguard the long-term interests of social development, which may conflict with students' needs to a certain extent. If students can't agree with the purpose and content of education, they will adopt a passive attitude and even have a rebellious attitude. This requires students to accept and understand ideological and political education, and practice moral norms. Third, students should take the initiative to carry out self-education. On the basis of classroom teaching of ideological and political courses, they should strengthen their theoretical accomplishment, improve their own quality and internalize classroom teaching theory into their hearts. At the same time, students should actively participate in practical activities, restrain their behavior with strict standards, be diligent in reflection, move from heteronomy to self-discipline, and actively understand and transform the objective world.

\section{CONCLUSIONS}

To sum up, "to strengthen and improve the classroom teaching of ideological and political courses is the key to promote ideological and political education in an all-round way" [6]. It is necessary to effectively understand the importance of ideological and political class teaching, objectively point out the problems in the teaching process, analyze the most important contradictions from these problems, and put forward the correct path to solve the problems step by step. Only by constantly improving the effectiveness of ideological and political class teaching in colleges, can we meet the requirements of the overall development of college students, improve the comprehensive quality of teachers, and implement the fundamental task of cultivating students by virtue. 


\section{REFERENCES}

[1] Huang Rongsheng, Cui Jian. The ideological and political work in colleges and universities adheres to the mission of building a virtuous people [J]. China Higher Education, 2019(22).

[2] Zhang Yaocan, Yongting Zheng, Wu Qiantao, etc. Modern Ideological and Political Education [M]. Beijing: People's Publishing House, 2006.

[3] Zhao Yao, Wang Jianxin. Value implication, problem research and optimization strategy of "double-line teaching" of ideological and political theory course in colleges and universities in the new era [J]. Ideological Education Research, 2021(01).

[4] Zhang Yuanyuan, Zeng Hao. Four Classrooms: Promoting the Teaching Reform of "Introduction to Basic Principles of Marxism" [J]. Research on Ideological and Political Course, 2020(06).

[5] Xi Jinping presided over the symposium of teachers of ideological and political theory courses in schools, emphasizing: casting souls and educating people with socialism with Chinese characteristics in the new era, implementing the party's educational policy, and implementing the fundamental task of building morality and educating people [N]. People's Daily, 2019-03-19.

[6] Liu Li. Research on Innovation Path of Ideological and Political Theory Teaching in Colleges and Universities in the New Era [J]. Comparative Study of Cultural Innovation, 20204(31) 